\section{SAT0625 SARCOIDOSIS IS ASSOCIATED WITH AN INCREASED RISK OF GASTROINTESTINAL EVENTS: A POPULATION-BASED RETROSPECTIVE COHORT STUDY $1976-2013$}

P. Ungprasert ${ }^{1}$, C.S. Crowson ${ }^{2}$, E.L. Matteson ${ }^{2} .{ }^{1}$ Research and development, Faculty of Medicine Siriraj Hospital, Mahidol University, Bangkok, Thailand; ${ }^{2}$ Rheumatology, Mayo Clinic, Rochester, USA

Background: An increased risk of gastrointestinal (Gl) diseases has been observed in several chronic inflammatory disorders but the risk in patients with sarcoidosis is not known.

Objectives: This study was undertaken to characterise the risk of Gl diseases in patients with sarcoidosis.

Methods: A population-based cohort of 345 incident cases of sarcoidosis among Olmsted County, Minnesota residents in 1976-2013 was identified from a comprehensive medical record-linkage system. Diagnosis was confirmed by individual medical record review. A cohort of 345 sex and age-matched comparators was also identified from the same underlying population. Medical records of both groups were reviewed for Gl diseases. Cox models adjusted for age, sex and calendar year were used to compare the rate of development of Gl diseases between the groups.

Results: Gl events occurred in 101 cases and 63 comparators, corresponding to an adjusted hazard ratio (HR) of 1.90 (95\% confidence interval [Cl] 1.38-2.61). Patients with sarcoidosis had an increased risk for both upper (HR 1.90; $95 \% \mathrm{Cl}$ 1.27-2.83) and lower Gl events (HR 1.97; 95\% Cl 1.27-3.05) relative to comparators. By disease type, patients with sarcoidosis had a significantly elevated risk of upper Gl ulcer, upper Gl haemorrhage and diverticulitis (table 1).

\begin{tabular}{|c|c|c|c|c|c|c|c|}
\hline Comorbidity & $\begin{array}{l}\text { Number } \\
\text { of } \\
\text { events } \\
\text { prior to } \\
\text { index } \\
\text { date }\end{array}$ & $\begin{array}{c}\mathrm{p}- \\
\text { value }\end{array}$ & $\begin{array}{c}\text { Number } \\
\text { of } \\
\text { events } \\
\text { after } \\
\text { index } \\
\text { date }\end{array}$ & $\begin{array}{c}\text { Cumulative } \\
\text { incidence at } \\
10 \text { years for } \\
\text { non- } \\
\text { sarcoidosis } \\
\text { subjects } \\
( \pm \mathrm{SE})\end{array}$ & $\begin{array}{l}\text { Cumulative } \\
\text { incidence } \\
\text { at } 10 \text { years } \\
\text { for } \\
\text { sarcoidosis } \\
\text { patients } \\
\text { ( } \pm \text { SE) }\end{array}$ & $\begin{array}{c}\text { Hazard } \\
\text { ratio } \\
(95 \% \mathrm{Cl})\end{array}$ & $\begin{array}{c}p- \\
\text { value }\end{array}$ \\
\hline \multicolumn{8}{|c|}{ Upper Gl diagnoses } \\
\hline Upper ulcer & $21 / 19$ & 0.87 & $11 / 27$ & $1.9(0.2,3.6)$ & $\begin{array}{c}4.5(2.0 \\
6.8)\end{array}$ & $\begin{array}{r}2.56 \\
(1.27 \\
5.17)\end{array}$ & 0.008 \\
\hline Upper bleed & $6 / 14$ & 0.11 & $14 / 29$ & $0.9(0.0,2.0)$ & $\begin{array}{c}4.4(1.9 \\
6.9)\end{array}$ & $\begin{array}{c}2.36 \\
(1.24, \\
4.47)\end{array}$ & 0.008 \\
\hline $\begin{array}{l}\text { Upper } \\
\text { perforation }\end{array}$ & $2 / 0$ & 0.50 & $0 / 1$ & - & - & - & - \\
\hline $\begin{array}{l}\text { Upper } \\
\text { obstruction }\end{array}$ & $1 / 3$ & 0.62 & $7 / 8$ & $1.4(0.0,2.7)$ & $\begin{array}{c}0.3(0.0 \\
0.9)\end{array}$ & $\begin{array}{r}1.20 \\
(0.43, \\
3.32)\end{array}$ & 0.72 \\
\hline Esophagitis & $7 / 4$ & 0.55 & $18 / 27$ & $3.6(1.4,5.8)$ & $\begin{array}{c}5.4(2.7 \\
8.1)\end{array}$ & $\begin{array}{l}1.58 \\
(0.87, \\
2.88)\end{array}$ & 0.13 \\
\hline $\begin{array}{l}\text { Esophageal } \\
\text { varices }\end{array}$ & $0 / 3$ & 0.25 & $1 / 6$ & $0.0(0.0,0.0)$ & $\begin{array}{c}0.7(0.0 \\
1.8)\end{array}$ & $\begin{array}{l}6.51 \\
(0.78 \\
54.16)\end{array}$ & 0.083 \\
\hline \multicolumn{8}{|c|}{ Lower Gl diagnoses } \\
\hline Lower ulcer & $2 / 1$ & 1.0 & $2 / 7$ & $0.6(0.0,1.4)$ & $\begin{array}{c}1.4(0.0 \\
2.8)\end{array}$ & $\begin{array}{c}3.51 \\
(0.73, \\
16.92)\end{array}$ & 0.12 \\
\hline Lower bleed & $5 / 3$ & 0.72 & $12 / 15$ & $1.8(0.2,3.3)$ & $\begin{array}{c}2.9(1.0 \\
4.8)\end{array}$ & $\begin{array}{l}1.32 \\
(0.62, \\
2.82)\end{array}$ & 0.48 \\
\hline $\begin{array}{l}\text { Lower } \\
\text { perforation }\end{array}$ & $0 / 0$ & - & $2 / 1$ & - & - & - & - \\
\hline $\begin{array}{l}\text { Lower } \\
\text { obstruction }\end{array}$ & $0 / 2$ & 0.50 & $1 / 2$ & - & - & - & - \\
\hline Diverticulitis & $3 / 2$ & 1.0 & $9 / 18$ & $0.4(0.0,1.1)$ & $\begin{array}{c}2.3(0.6 \\
4.0)\end{array}$ & $\begin{array}{c}2.29 \\
(1.03, \\
5.10)\end{array}$ & 0.043 \\
\hline $\begin{array}{l}\text { Ischaemic } \\
\text { colitis }\end{array}$ & $2 / 0$ & 0.50 & $3 / 7$ & $0.0(0.0,0.0)$ & $\begin{array}{c}0.6(0.0 \\
1.5)\end{array}$ & $\begin{array}{l}2.38 \\
(0.61, \\
9.26)\end{array}$ & 0.21 \\
\hline $\begin{array}{l}\text { Infectious } \\
\text { colitis }\end{array}$ & $1 / 5$ & 0.22 & $7 / 13$ & $0.6(0.0,1.5)$ & $\begin{array}{c}2.9(0.9 \\
4.9)\end{array}$ & $\begin{array}{l}1.99 \\
(0.79, \\
5.00)\end{array}$ & 0.14 \\
\hline
\end{tabular}

Conclusions: Patients with sarcoidosis have a higher risk of both upper and lower Gl events compared with subjects without sarcoidosis.

Disclosure of Interest: None declared

DOI: 10.1136/annrheumdis-2018-eular.4365

\section{SAT0626 \\ ANAKINRA TREATMENT IN REFRACTORY CASES OF ADULT-ONSET STILL DISEASE: CASE SERIES}

S. Ugurlu, B. Yurttas, G. Guzelant, B. Ergezen, H. Ozdogan. Division of Rheumatology, Department of Internal Medicine, Cerrahpasa Medical Faculty, University Of Istanbul, Istanbul, Turkey

Background: Despite methotrexate and steroid treatment, in cases of Adultonset Still's disease (AOSD) it is usually difficult to maintain clinic stability. In refractory cases, Anakinra treatment has been reported to be efficacious. ${ }^{1}$

Objectives: In this retrospective review, it is aimed to evaluate the AOSD cases treated with anakinra in our centre.

Methods: Fourteen AOSD patients ( 11 female, 3 male) who were being followed in our outpatient clinic were reviewed retrospectively. The demographic characteristics, pre- and post-treatment clinical findings were reported.

Results: The mean follow-up period of the patient population was $33.5 \pm 30.07$ months (mean $\pm S D$ ). Initial prednisolone dose was $37.3 \mathrm{mg} /$ day. Except for one, all of our patients were exposed to methotrexate before being treated with anakinra. This patient was being treated with cyclosporine instead, since she had concomitant Macrophage Activation Syndrome. The other medications, the patients were previously treated with, were Etanercept $(n=2)$, Tocilizumab $(n=3)$, Infliximab $(n=1)$ and Adalimumab $(n=1)$.

All patients were on $100 \mathrm{mgs}$ of Anakinra, daily, except for the one treated with $200 \mathrm{mg} /$ day. The mean duration of Anakinra therapy was 11.4 months. Among 7 patients in whom anakinra therapy was terminated, 1 had drug induced urticaria, 1 was primary irresponsive, 4 were secondary irresponsive and the other had severe pneumonia. Primary irresponsiveness is the lack of response to the therapy since the drug was first introduced, whereas in secondary irresponsiveness the case responds to the medication for a while and starts to flare again after asymptom-free period on the medication. Among 14, 7 of our patients are still on $100 \mathrm{mg} / \mathrm{d}$ Anakinra

The mean level of $\mathrm{C}$ reactive protein (CRP) measures was reduced from 64.38 $\pm 61.95 \mathrm{mg} / \mathrm{L}$ to $34.3 \pm 24.3 \mathrm{mg} / \mathrm{L}$ with Anakinra therapy $(p=0.003)$. Similarly, mean Erythrocyte Sedimentation Rate (ESR) was dropped to $33 \pm 22 \mathrm{~mm} / \mathrm{h}$ from 59 $\pm 35 \mathrm{~mm} / \mathrm{h}$ by the help of the therapy $(p<0.001)$. Among patients who primarily responded Anakinra therapy the mean Ferritin measures dropped to $427.25 \mathrm{ng}$ $\mathrm{ml}$ from $910 \mathrm{ng} / \mathrm{ml}(\mathrm{p}=0.006)$. On the other hand, the Ferritin level was not significantly reduced in patients who did not respond Anakinra.The mean Patient reported Global Visual Analogue Scale (PG-VAS) score was also decreased to $3.83 \pm 4.7$ from $9.5 \pm 0.07$ following the therapy $(p<0.001)$. Unfortunately, one of our 7 patients who were followed in remission under Anakinra died of an unknown etiology.

Conclusions: Adult-onset Still's disease is a challenging disorder, lacking a sufficient long-time clinical control. In order to obtain a full remission, various efforts have been spent so far. One of these approaches is to treat refractory cases with Anakinra, an IL-1 blocking agent. According to our clinical experience we state that, anakinra has a relatively high efficacy in controlling refractory cases.

\section{REFERENCE:}

[1] Ortiz-Sanjuán F, et al. Efficacy of Anakinra in RefractoryAdult-OnsetStill'sDisease: MulticenterStudyof 41 PatientsandLiteratureReview. Medicine (Baltimore) 2015 Sep;94(39):e1554.

Disclosure of Interest: None declared

DOI: 10.1136/annrheumdis-2018-eular.6908

\section{SAT0627 FABRY DISEASE: DIAGNOSTIC ERRORS IN RHEUMATOLOGY PRACTICE}

S. Moiseev ${ }^{1,2}$, P. Novikov ${ }^{1}$, N. Bulanov ${ }^{1}$, E. Karovaikina' ${ }^{1}$, A. Moiseev ${ }^{2}$, V. Fomin ${ }^{1}$.

${ }^{1}$ Sechenov First Moscow State Medical University (Sechenov University);

${ }^{2}$ Lomonosov Moscow State University, Moscow, Russian Federation

Background: Fabry disease $(F D)$ is a rare $X$-linked storage disease resulting from the deficient activity of the lysosomal a-galactosidase $A$ (AGAL) and leading to a progressive accumulation of glycosphingolipids in a wide range of cell types throughout the body, including kidney, heart and nervous system. Certain manifestations of FD can mimic those of rheumatic diseases.

Objectives: To evaluate the occurrence and the possible causes of diagnostic errors in patients with FD in rheumatology practice.

Methods: We retrospectively studied the medical records of 82 adult patients with definite FD (low or absent AGAL activity, pathogenic mutation in the GLA gene, typical clinical symptoms in patient and/or his relatives, results of kidney biopsy). There were 55 males and 27 females aged of 18 to 69 years (median $38^{29 ;} 48$ years).

Results: Seventy two of 82 patients $(87.8 \%$ ) had a history of classic phenotype of FD from childhood or adolescence. The typical manifestations included neuropathic pain that was related to heat and fever (65/82; 79\%), angiokeratoma (37/ 